\title{
O que Existe por trás das Atitudes de uma Professora?
}

Sadalla, A.M.F.A., (1998). Com a palavra. a professora: suas crenças. suas ações. Campinas: Editora Alínea, 136 .

As professoras, em sua atuação na sala de aula, apresentam atitudes e expectativas diferenciadas ao lidar com seus alunos, variando também a didática e a metodologia empregadas. Pesquisas realizadas relatam que tais diferenças são decorrentes de crenças construídas pela professora ao longo de sua trajetória pessoal e profissional. Objetivando estudar as influências exercidas pelas crenças das professoras em suas atitudes frente aos alunos, Ana Maria Falcão de Aragão Sadalla desenvolveu o presente livro, o qual é fruto de sua pesquisa de Doutorado.

Estruturado em cinco capítulos, o livro descreve com detalhes, o estudo de caso realizado pela autora em sua pesquisa de Doutorado, a qual aborda os pensamentos e crenças de uma professora alfabetizadora em sua sala de aula.

No Prefácio, Sérgio Antonio da Silva Leite, da Faculdade de Educação da Unicamp, discorre sobre aspectos relacionados à formação de professores, o problema do fracasso escolar e seus determinantes, e a influência das crenças no desempenho acadêmico e na percepção que o professor tem de seus alunos.

Na Apresentação, a autora relata experiências e fatos de sua história pessoal e profissional que contribuíram para a elaboração e desenvolvimento de sua tese de Doutorado e na transformação desta em livro. É oferecida também ao leitor, uma breve descrição de como está estruturado o livro, com explicitações dos principais tópicos apresentados em cada um dos cinco capítulos.

o Capítulo I conta um pouco da história relacionada à prática do professor, suas crenças e sua imagem, ressaltando a influência das crenças na prática profissional. Em sua primeira parte intitulada "O Pensamento do Professor", apresenta um breve histórico e uma descrição das pesquisas realizadas sobre as crenças e os pensamentos do professor, a diferença entre crença e atitude, oferecendo ao leitor a oportunidade de perceber a influência das crenças na prática pedagógica e na visão do que seja ensinar.

Completando o Capítulo I, a autora discute em "O professor prático reflexivo" aspectos relacionados à imagem e o papel do professor no período da industrialização, a necessidade de mudanças, e a importância das expressões "prático - reflexivo" e "ensino reflexivo", utilizadas como símbolo nas campanhas pela reforma do ensino e na formação de professores. Os conceitos "prático - reflexivo" e "ensino - reflexivo" são explicitados e relacionados à prática do professor, ressaltando-se ao final do capítulo, a importância deste profissional pensar sobre sua prática, organizar suas próprias teorias, e compreender as influências de suas crenças no processo de ensino - aprendizagem.

O Capítulo II "Descrevendo a pesquisa: a metodologia utilizada", oferece ao leitor, informações sobre as dificuldades enfrentadas pela autora para encontrar uma professora disposta a permitir a filmagem de suas aulas. Em seguida, discorre sobre a trajetória pessoal e profissional desta professora, apresenta a maneira como ela percebe seus alunos, e as expectativas que tem.

Definido e descrito o sujeito da pesquisa, a professora "Letícia", a autora descreve com 
detalhes a técnica utilizada para coleta de dados, a autoscopia, e os momentos em que foram realizadas as filmagens em sala de aula.

O Capítulo II é finalizado, com a descrição de como os dados coletados foram analisados, apresentando as categorias e subcategorias encontradas pela autora na análise das crenças da professora, as quais estão divididas em dois conjuntos amplos denominados: "o grupo classe" e "o desempenho escolar".

O Capítulo III "As crenças da professora Letícia", apresenta os resultados encontrados de forma detalhada. Para cada crença categorizada, estão relacionados exemplos de falas da professora, e comentários da autora relacionando crenças subjacentes. Este é um capítulo de fácil leitura e que, devido aos exemplos oferecidos, pode proporcionar aos educadores momentos de reflexão sobre suas crenças e práticas profissionais e pessoais.

O Capítulo IV "As ações da professora Letícia: suposições a partir das crenças", apresenta implicações das crenças da professora em sua atuação docente, discutindo possíveis relações entre seu pensamento e sua ação diante dos alunos. Os dados obtidos são comparados a resultados encontrados em outras pesquisas, e hipóteses são levantadas para justificar as crenças da professora. É ressaltado neste capítulo, a importância dos professores terem consciência de suas crenças e de seus pressupostos no processo de ensino - aprendizagem.

No Capítulo V, "Um estudo sobre crenças e ações: considerações finais", a autora levanta as implicações de seu estudo, os profissionais que podem se beneficiar das análises realizadas, e a importância das pessoas envolvidas no processo educacional reconhecerem e discutirem as relações entre crenças e ações docentes já no período de sua formação.

É discutido também neste último Capítulo, o papel das universidades na formação das crenças dos professores, e a importância da formação continuada como momento de discussão das crenças e teorias subjacentes às ações dos docentes, bem como a importância do professor tomar a própria ação como objeto de reflexão.

Nas últimas páginas do livro, é possível encontrar as referências bibliográficas citadas pela autora ao longo dos Capítulos, as quais possibilitam ao leitor uma oportunidade de aprofundar-se nesta temática.

Este livro é indicado aos profissionais ligados e interessados na área educacional (professores, monitores, orientadores pedagógicos, psicólogos e outros educadores), a todos aqueles que atuam junto a crianças e adolescentes, e também aos que se interessam pelo tema. Sua leitura é agradável e possibilita momentos de reflexão sobre a prática profissional, e a maneira de reagir diante de fatos e pessoas.

\section{Patricia de Carmo Pereira}

Recebido em outubro 1998. Encaminhado para revisores em outubro 1998. Encaminhado para revisão do autor em abril 1999. Aprovado em abril 1999. 